\title{
Eliot Freidson's sociology of professions: an interpretation for Health and Nursing
}

\author{
Sociologia das profissões de Eliot Freidson: interpretação para a Saúde e Enfermagem \\ Sociología de las profesiones de Eliot Freidson: interpretación para la Salud y la Enfermería
}

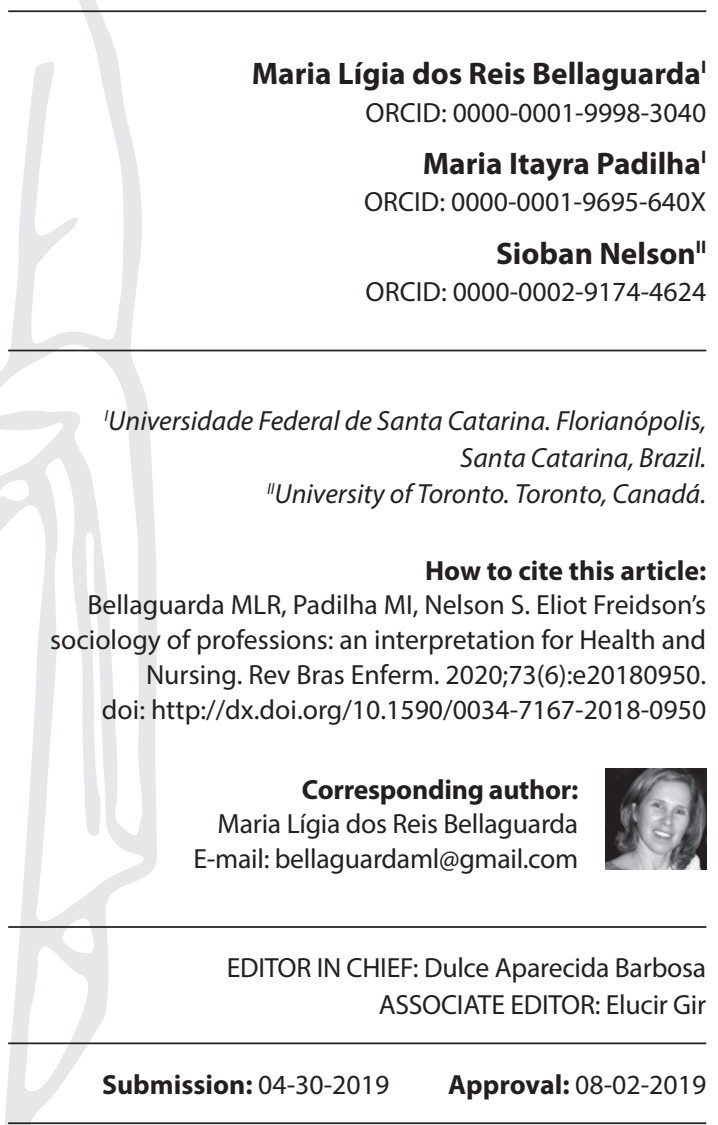

\begin{abstract}
Objectives: to analyze theoretical conceptions of Eliot Freidson's Sociology of Professions scoped on health and nursing professions. Methods: Eight nurses were interviewed, all involved in the development of the professional Council on the timeframe from 1975 to 1986. Documental resources were Laws, Ordinances, Resolutions, Reports, Meeting Minutes and Public Deeds. Information was organized as from literature and Eliot Freidson's conceptions, and thematic content analysis was carried out. Results: the concepts authored by Eliot Freidson allowed for the development of a concept chart that portrays the nursing profession and that may be expanded for the other occupations in the health field, in consonance with professional organization in the country. Final Considerations: Eliot Freidson's framework, in interpretation for nursing, consolidates the profession with relative autonomy, expertise by Nursing Care Systematization and credentialism by professional normalizations.

Descriptors: Nursing; Health Professions; Professional Normalization Organization; History; Sociology.
\end{abstract}

\section{RESUMO}

Objetivos: analisar as concepções teóricas da Sociologia das Profissões de Eliot Freidson para o âmbito das Profissões da Saúde e da Enfermagem. Métodos: estudo qualitativo sócio-histórico, com fontes orais e documentais. Foram entrevistados oito enfermeiros envolvidos no desenvolvimento do Conselho profissional no recorte temporal de 1975 a 1986. As documentais foram Leis, Portarias, Resoluções, Relatórios, Atas de Reuniões e Escrituras Públicas. As informações foram organizadas a partir da literatura e concepções de Eliot Freidson, $e$ realizada análise de conteúdo temática. Resultados: os conceitos emitidos por Eliot Freidson permitiram a criação de um Quadro conceitual que representa a Profissão Enfermagem, podendo ser ampliado para as demais profissões da área da Saúde, em consonância com a organização profissional no país. Considerações Finais: o referencial de Eliot Freidson, em interpretação para a Enfermagem, consolida a profissão com autonomia relativa, expertise pela Sistematização da Assistência de Enfermagem e credencialismo pelas normalizações profissionais.

Descritores: Enfermagem; Profissões da Saúde; Organização de Normalização Profissional; História; Sociologia.

\section{RESUMEN}

Objetivos: analizar las concepciones teóricas de la Sociología de las Profesiones de Eliot Freidson para el alcance de las profesiones de salud y enfermería. Métodos: estudio sociohistórico cualitativo, con fuentes orales y documentales. Se entrevistó a ocho enfermeras involucradas en el desarrollo del Consejo Profesional en el período de 1975 a 1986. Los documentales fueron Leyes, ordenanzas, resoluciones, informes, actas de reuniones y escrituras públicas. La información se organizó a partir de la literatura y las concepciones de Eliot Freidson, y se realizó un análisis de contenido temático. Resultados: los conceptos emitidos por Eliot Freidson permitieron la creación de un marco conceptual que represente a la profesión de enfermería, que podría ampliarse a otras profesiones de la salud, en línea con la organización profesional del país. Consideraciones Finales: el marco de Eliot Freidson, en interpretación de enfermería, consolida la profesión con relativa autonomía, experiencia en Sistematización de la Atención de Enfermería y credencialismo en los estándares profesionales.

Descriptores: Enfermería; Profesiones de Salud; Organización de Normalización Profesional; Historia; Sociología. 


\section{INTRODUCTION}

History contributes to founding purposes and decision making within a profession. Moreover, it is from the understanding of the historical development of events experienced by the profession that the construction of identities at the core of the professional category is made. Representative entities for a profession reveal the intention dynamics and the transformations in economic, cultural, social and political contexts in the labor world, which direct life in society.

By bringing up the development of nursing professional organization in the state of Santa Catarina, Brazil, through the lens of Eliot Freidson's studies ${ }^{(1)}$, the influences that structure brings to the profession are made evident and an expansion of its discussion to health field occupations in general is sought out. Understanding that the expansion and consolidation of an occupation happens through its professional organization and through the professionalism of its members allowed the authors of this study to interpret Freidson's concepts to the sociological dynamic of health and nursing.

In Freidson's studies, in order to fit the concept of profession, a subject must have its own schools, present educational credentialism, and have regulations and professional directives for work, with superficial autonomy ${ }^{(2)}$. In the author's perspective, the ideal of professionalization is composed of interdependent elements, specialized labor due to a specific theoretical corpus, and ethics on the use of knowledge and professional skills. Moreover, it is consolidated by social acknowledgement of labor, formal teaching programs, credentials, division of labor and its own jurisdiction.

Three factors characterize a profession according to Freidson ${ }^{(2)}$ : technical autonomy, knowledge/expertise and credentialism upon its own labor. For him, society is formed by the population and the environment where people live and establish relations through an identity and sense of belonging. This society is part of the State, which is the politically organized nation, constituted by the people and which follows rules of legal, ethical, cultural, religious and social conduct ${ }^{(3)}$.

The sociological approach of this study is justified by the discussions Freidson brings up about profession. And, mainly, because it brings discussions to the health field that are pertinent to what he calls consulting occupations ${ }^{(4)}$. Although Freidson remarks that nursing is a semi-profession, because it does not correspond to the "ideal type"(4) described for other professions, such as medicine ${ }^{(4)}$, it is understood that the suitability of this theoretical basis supports nursing as a science, art, subject and profession. Thus, this study intends to bring the nursing profession under analysis with the same complexity and comprehensiveness degree that others in the health field.

\section{OBJECTIVES}

To analyze theoretical conceptions of Eliot Freidson's Sociology of Professions scoped on health and nursing professions.

\section{METHODS}

\section{Ethical aspects}

This research was assessed and approved by the Research Ethics Committee of Universidade Federal de Santa Catarina. All instruments related to data gathering of oral and documental information were validated by the response to developed analysis. Validity of information presented in interpretations results from cross-referencing oral statements, documentation and Freidson's Sociology of Professions.

\section{Type of Study}

Socio-historical research with descriptive-interpretative approach from the theoretic-sociological construing of professions by Eliot Freidman, scoped on nursing.

\section{Methodologic procedures}

Information was gathered from oral and documental sources ${ }^{(5)}$. Interviews with eight Nurses lasted from 30 to 80 minutes, guided by questions related to the development of the professional council and of the nursing profession in the State of Santa Catarina, and they were transcribed and identified with the participants' consent. Documental sources sorted in catalogs were Laws, Ordinances, Resolutions, Sentences, Reports, Meeting Minutes and Public Deeds, with documental information regarding the series, research-relevant content in the document, sender, recipient, identification codes, signatures and dates. Data were gathered in 2013.

\section{Study setting}

Brazilian Nursing Association (ABEn - Associação Brasileira de Enfermagem), Brazilian Nursing Association - Santa Catarina Chapter (ABEn-SC - Associação Brasileira de Enfermagem-Seção Santa Catarina), Federal Nursing Council (COFEN - Conselho Federal de Enfermagem), and Santa Catarina Regional Nursing Council (COREN-SC - Conselho Regional de Santa Catarina) were the contexts used in documental investigation. They were also the spaces where the eight participant nurses were chosen for this study, since they were involved in the development of the professional Council in the timeframe from 1975 to $1986^{(6)}$. Inclusion criteria for the oral sources required that they be professionals who took part in the development of the Professional Council in the State of Santa Catarina. Documental sources in use were produced by representation entities of the profession, or social entities, or private sources (received by individuals) who influenced nursing practice and assisted its historiography.

\section{Data analysis and treatment}

Focus was centered on Freidson's sociological concepts ${ }^{(7)}$ : expertise/knowledge, credentialism, autonomy, professional status, Society and State. Firstly, there was pre-analysis by continuous reading of oral history and documents about the professional Council in Santa Catarina. The concepts pointed out which material should be explored, so inference and interpretation of information moved forward. Finally, there were the resulting subcategories that bring up the interpretation of Freidsonian concepts for professions, contextualizing them for nursing.

\section{RESULTS}

Analysis of statements by oral sources, cross-referenced to documental sources, made it possible to carry out an interpretative 
analysis as from professional organization dynamics, based on Freidson's theoretical sociologic framework. From the gathered statements, from the oral enunciation of study participants, the interdependent elements of a profession reflect on nursing with credentialism, expertise and autonomy. Thus, it standardizes its professional actions and behaviors to self-regulation, through professional organizations and in relation with the State. From emerging significations, interpreted by credentialism, they verse on self-regulation, ethics, autonomy, professional organizations, labor, and professionalism as some statements below:

It was a flag hoisted by nursing, that it was a professional definition to have its own Council. (Solange Wink)

The Council would come to change the offer of budget, to demand that health care units had nurses, to make it so that dream nursing could come true. (Ingrid Elsen)

We had very firm values to be preserved by nursing. The ideal of the profession, professional stance and ethics were what prevailed. (Eloita Pereira Neves)

Credentialism takes shape from particular and specific expertise/knowledge of the profession.

We committed to the group, it had to grow, develop, motivate people to take the Course, bring more people over, because the needs here were dire. (Nelcy Teresinha Coutinho Mendes)

The principle of professional groups lies in the autonomy/ self-regulation that each group has over its own labor, however the power over professional performance is not clearly observed, in order to base autonomy. Autonomy is the power of a profession to control its own labor, but so it is guaranteed by society.

There was indeed an increase both in relation to the Council's acknowledgement, and to the profession that was starting to be acknowledged, the Nursing Profession. (Lydia Ignes Rossi Bub)

We have a profession that is still very attached to others in the health field, that is to say, this discussion about autonomy, about what really is the role. Today we perform about $90 \%$ or more activities in the health area. Even so everyday [you] have to prove that your profession is important. (Edison José Miranda)

Autonomy is understood as relative, since it is presented in relations that are professional/professional, professional/society and professional/professional from other areas. Thus, society is comprised by the professional group, the protagonists of the care to be provided and by the social ensemble that is organized and managed by the State. State relations with the professions is established through their Representative Bodies, which regulate and inspect professional activity.

The Council was created and was immediately absorbed by the Nursing School of Universidade Federal de Santa Catarina and by large Hospitals. (Rosita Alves da Silva Morgado)

Nursing requires specific graduation at college/university level, where its education is made from self-regulation credentials and controlled by the professional group itself. It presents a specific theoretical corpus and its ethical practice is defined by the ethics code, required in the internal scope of the profession, regulated and inspected by its own representative body.

[People] already talked about the difficulties in creating a Council, when it was still questioned whether it was a profession. Therefore, I think this is a constant fight, I don't know if it's over of if we still have to prove we are a profession. (Eloita Pereira Neves)

We wanted an emancipated, correct nursing. It was the patient who was our center, we wanted him in good care conditions, so it was a matter of idealism and we were incredibly strong. (Lúcia Herta Rockembach)

The statements, identified and interlinked to the framework sociologic concepts, elucidate the central axis Nursing Profession in the picture, circled by the contexts of credentialism, autonomy, expertise/knowledge, Society, State and professional status. Professional status, according to interpretation, meets the view the profession has of itself, grants value to the specificity of professional activity, acknowledges the diversity in the environment it is part of, improves expertise and takes support in self-regulation. Thus, these statements influence the social structure and reaffirms its professional status. Concept representation presents it, what brings to the discussion a sociological interpretation of professions by Freidman to nursing.

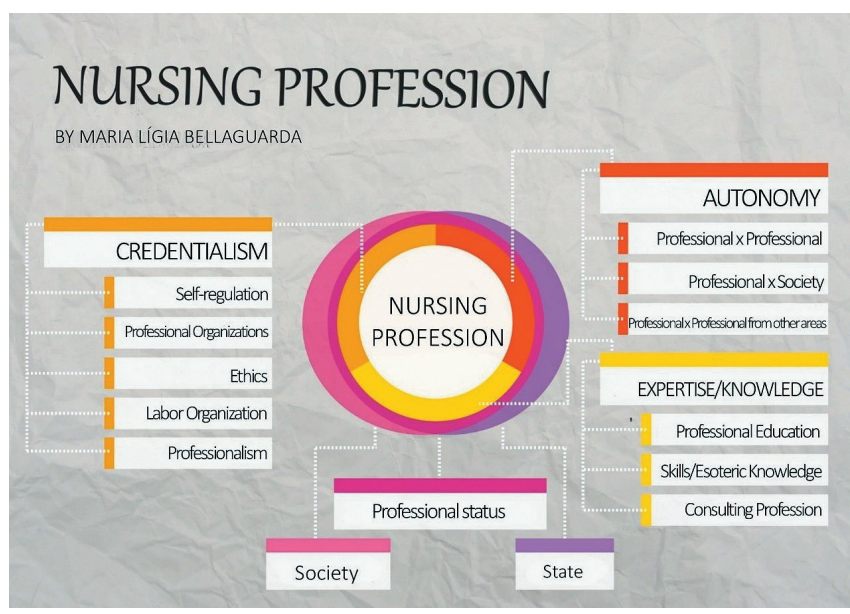

Figure 1 - Representation of Nursing Profession, Florianópolis, Santa Catarina, Brazil, 2017

\section{DISCUSSION}

In the multiple health care settings where nursing professionals carry out their labor, from health education in communities to hospital-level care, diagnostic analysis is involved amidst Nursing Care Systematization (NCS). This activity comprises the thinking and acting processes in the definition of a health plan, seeking to reach goals and record the evolution of all health and care history of the being under care. Those are actions that demand professional autonomy of knowledge, skill and behavior during provision of health care by nurses.

It is necessary that a profession ${ }^{(1)}$ hold monopoly over its professional activities. That brings us back to the professional 
practice of nurses, when they carry out their activities within technical, technological, scientific and ethical standards, which require systematization of care to be provided.

Therefore, nursing may be considered a characteristically autonomous profession, given the complexity of all structure and organized knowledge around NCS. Thus, it follows the point that "technical autonomy is in the essence of what is particular and exclusive to the profession"(1). It also means that the revindication for a position of autonomy takes form in esoteric or complex skills of its specificity ${ }^{(1)}$.

Professional autonomy is, for Freidson, a quality that grants power to the profession, which reaches its status when it performs its actions under the protection of society and State control. That esoteric knowledge or skill is understood as the ability that is acquired from knowledge from different fields and of professional training, which laymen and professional of other areas do not have control over complex and exclusive knowledge from a profession ${ }^{(1)}$. In that perspective, professional self-regulation shows itself as a factor for autonomy when nursing presents its own legislation regarding that complex knowledge and the professional activity based on NCS, as it can be identified in COFEN Resolution n. 358 from October 15, 2009(8-9).

Freidson's writings show nursing as an occupation or even as a para-professional activity, which depends on the will of another professional to perform practice. By showing that a profession makes its autonomy evident when it does not need others to interact in reality, he resorts, then, to an incongruence between professional autonomy and the characteristics of a profession against the values of a profession ${ }^{(10)}$. If the status of a profession depends on its credentialism, on laws, on specific and complex knowledge, and on its relation with State and society, they reflect its relative, interdependent autonomy.

Freidson's point about autonomy ${ }^{(1)}$ lies on the power of a profession over its labor, but that it is guaranteed by society. That sociologist considers it a quality that grants power to the profession, which reaches its status ${ }^{(11)}$. In that approach, professional status is the position of legal and technical authority over labor division in an occupation. The position of importance and necessity that the profession presents within society are specific traits that make the profession needed and openly important to the solution of health and sickness situations, when it comes to health field professions.

It is characterized by specialized labor, specific theoretical corpus, ethics on expertise use, formal graduation program, and acknowledgement of professional labor by society. It reaffirms the goals of the professional project ${ }^{(12)}$, through the legal acknowledgement by the State and professional legislation as instruments of identity character. It defines who can and cannot perform, carry out the profession.

The relation among State, agents and official bodies formalizes the profession and grant it control of occupation on its labor. In that sense, this autonomy brings to the discussion self-regulation and its relation with the professional organization and with the political interests of the State ${ }^{(1)}$. The technical aspect of labor is under responsibility of the profession, whereas economic and social organization of labor are under State responsibility. Knowledge production and knowledge itself equip the decision-making process and class struggles for adequate work conditions, which include: wages; work shifts; retirement and work agreement rules; environment and quantity and quality of safe, technologically appropriate work instruments; personal and collective protection equipment; personnel size and adequate labor division ${ }^{(13)}$. It is essential to create policies that support the fight for appropriate labor law on health and nursing work and, essentially, for addressing the health necessities of the population.

Expertise or knowledge are understood as a body of possibly true facts, sorted by some ideas or theories that provide the formal essence of experts' learning in professional schools ${ }^{(1)}$. Freidson states that, in order to be considered a profession, an occupation requires the inclusion of specific graduation, training and construction of particular knowledge, as presented in all his writings since the 1970's. That is a highlight in the Freidson's Sociology of Professions, since he grants value to cognition perspective, which brings explanations about professional organization and, from specific knowledge, they reach autonomy.

Therefore, graduation must be subject to formal regulations, based on pertinent legislation as well as rulings and ordinances linked to political institutions, professional organizations and educational bodies. Moreover, Nursing Theories provide an organized knowledge corpus, which aims at guiding the events to be studied, conceptualize phenomena, facilitate communication through signification, and predict facts from observation towards discoveries.

Nursing Theories, from a Sociology of Professions perspective, are understood as the necessary expertise for the graduation of a nursing professional, since they assist the clarification and potential understanding of practices and events in the profession. Nursing Theories are propositions to contribute with nursing care and they allow the perception of relations between professionals and the individuals in need of care $^{(7,14)}$.

In that sense, the difference between profession and professionalism ${ }^{(1)}$ is important to the understanding that the former refers to the occupation itself and the latter refers to the stance and behavior during work performed by the professional. Profession is an occupation with a special position in labor division, an expertise that ensures the specificity of one's know-how and qualifying credentials granted by regulation professional bodies. Otherwise, professionalism is characterized by the ensemble defining attributes of professionals ${ }^{(1)}$. It is stated that professionalism exists independently from professional status.

The authors of this article interpret this semantic matter as pertinent, since the profession is not made separately from the worker who is comprised in it. Since it is impossible to address sociology around professional organization without analyzing the competence of individuals, who improve their knowledge aiming at the qualification and signification of their professionalism.

Professional knowledge or expertise, as defended by Freidson ${ }^{(1)}$, becomes more adequately assessed if professional labor is attentively observed. It is important to highlight that expertise, according to the framework, grants autonomy on control of problem definition under its power, such as the way work is performed. According to Eliot Freidson, "What professionals do represent their effective knowledge and expertise; the way who they regulate what they do to benefit public interest represents their effective orientation for service and ethics"(1). 
In that sense, professional labor regulation though legislation and codes of ethics applies, according to Freidson, to professionalism. Therefore, it does not guarantee that expertise and ethics, ruled by professional labor, shall ensure quality and regular assistance to people who depend on the practice off a specific professional group. However, Freidson's argument ${ }^{(1)}$ regarding the relation between knowledge and ethics is that the act of performing knowledge makes the professional activity be carried out by whom, essentially, has expertise.

Nursing presents itself as a profession which, throughout its history, has been building up a specific knowledge corpus that is outlined by ethical and self-regulatory principles ${ }^{(13)}$. It is pertinent to conceptualize nursing from Freidson's ideas, since his thoughts are fundamental to the development of this study. Nevertheless, at the same time that the sociologist's rhetoric discusses what characterizes a profession, it exposes an interpretation of nursing as a para-profession. It is understood that a framework may be the basis of a discussion, but it has to be interpreted and questioned, so knowledge is created and expanded. Thus, the authors of this study bring a concept of nursing that is outlined by Freidsonian ideas, but which disagrees with what is referenced in his writings.

The authors consider, therefore, that nursing is a health care Profession, based on scientific knowledge, on its self-regulation and in the autonomy of its performance through care, education and cooperative management practice to people, in interdependence with its peers and other health field professionals.

In the perspective of this paper, expertise creates the conditions so that members of nursing professional organization consolidate bases for autonomous practice and in the interest of competent and safe health care practice to society. Praxis aspects and professional performance guidelines legitimate nursing actions.

Qualifying credentials defined by nursing over its own labor lay on identity forms which this professional group assigns to itself in health care. Credentialism is shown as an ensemble of formal rules and regulations comprised in Laws or in regulations and ordinances linked to political institutions, professional associations and educational organizations ${ }^{(1)}$.

Credentialism poses as a protection to expertise; graduation through training and certification strategies as determined by associations are reaffirmed by a title or credential, thus assuming professional regulation by law and action by Professional Councils. Credentialism of a profession is a prerogative of institutionalization, of suitability of professional deontology, of accreditation of academic-professional graduation, and of adequation within the professional market. Autonomy of professions in the State is a resource that is seen as fundamental to professionalization. This is observed about self-regulation of professions, which is carried out by the representative body of each profession, such as the Orders, Associations and/or Councils. The creation and development of professional Associations and Councils is a reference to the acknowledgement of a profession. Furthermore, they appropriately give credentials to an occupation so it becomes a profession as acknowledges by the State and, thus, guarantees its utility to society.

Concerning nursing, its relation with the State is observed through qualification credentials regarding formal education and legal provisions for professional praxis (Act n. 7.498/86), which are guaranteed by the Professional Council of that labor class. ABEn shows the professionalization path of Brazilian nurses in interaction with construction of knowledge, professional qualification and organization of the profession until the foundation and development of COFEN.

Therefore, expertise takes shape on nurse school graduation, with training about the use and improvement of health care techniques and specific technologies. That knowledge is constructed through research and follows social transformations. Professional formation is understood, in this perspective, as the training, empowerment and construction of particular and specific knowledge, which grants technical and theoretical authority about certain areas.

Nursing theories and new ways to systematize health care bring to light the knowledge, the esoteric skill that is determined by a particular knowledge corpus and that defines nursing as a care profession. In that interpretation, consulting is added as a practice arising from expertise and self-regulation. Legal acknowledgement of nursing as a health field profession is established in the Professional Practice Act (Act n. 7.498/86), as well as in Ordinances from COFEN. In care practice, expertise is consolidated in health care provided to society in hospital, ambulatory and SUS (Sistema Único de Saúde - Brazilian Unified Health System) contexts, the latter through FHS (Family Health Strategy); also, in consulting practice at private health care centers ${ }^{(3)}$.

Knowledge that is formalized and granted to the in-training nurse improves, among other factors, health and nursing research, which expands in increments to intensify credentialism in the profession. The State intervenes through norms in the labor field, in response to political and economic movements. Therefore, it requires suitability, regulation and inspection from representative professional bodies, i.e., professional self-regulation of Associations and/or Councils. Regarding nursing, self-regulation corresponds to COFEN and its Regional chapters, in partnership with ABEn and worker's unions ${ }^{(3)}$.

That practice is reflected on labor organization and on the professionalism of members of a profession. That entire complex of concepts and characteristic organization in order to formalize a profession is only consolidated with the acceptance of society. That acceptance is based on the function of professional ethics in convincing State and society about the value of and necessity for a profession.

Disciplinary action and investigation of ethics complaints make the nursing professional council an important articulator in support networks for safe care practices to the population, relying on the Code of Ethics for Nurses. Professional organization corresponds to the practice of labor relations. The relationship among members of a profession, their relationship with individuals of other professions, and also with people/users of health services are all part of professional organization ${ }^{(8)}$. In that perspective, professional structure corresponds to a labor organization, since relations established between professionals follow the labor division in health and in nursing. Thus, it links a professional's individual quality to the conditions of the environment where labor is carried out and even to the network of formal and informal relations with peers and professionals of different professions. 
Autonomy is established by the relativization of authority presented by professions to self-govern. In the universe of professional organization there is the authority that happens in the scope of action development, which contemplates specific practices which are characteristic to nursing procedures. That refers to the autonomy among members of the nursing team, and among each member's set of responsibilities. Autonomy manifests in spaces where there is labor division of nursing among other professions, according to the specificity of knowledge fields defined and developed by them ${ }^{(3)}$.

It is understood that autonomy is observed among professionals of the same category, i.e., professional x professional autonomy, which is established from knowledge, labor self-regulation and organization, guidance and practice supervision relations within care and educational actions among members of the same category. Autonomy relativization is characterized, in nursing, by the limits that each member of the team presents to develop his/her activity and make use of his/her particular knowledge, skills and stance within the same specificity.

Upon understanding that nursing develops its actions with and to society, professional $x$ society autonomy is observed as the relation between the professional and the users of the services provided by this professional through the exclusive competence and expertise; it is freedom on care to be developed and on decision making, however sharing guidance and discussion with the members of society who use the specialized services.

The different relation formats in labor scope are understood in this study as professionals $x$ health care and other professionals' autonomy. That autonomy relation is perceived as the independence on actualization of particular activities of each professional field and freedom on decision making applied to education, management and care on scope of esoteric skill of each professional.

For the effectiveness of the latter autonomy, it is pertinent to make use of interdependence, co-participation and expertise sharing and training, in order to reach quality care for society, respecting the legal and ethical-professional limits of each professional organization ${ }^{(11)}$.

Regarding autonomy, we go back to Professional Practice Act (Act n. 7.498/86) which, in its "article 11", provides that "the nurse carries out all nursing activities, which are his responsibility: [...] c) planning, organization, coordination practice and assessment of nursing care services; [...] i) nursing consulting; j) nursing prescription; [...]"(8). It also declares the nurse's independence regarding the right to perform nursing consulting, as well as other prerogatives for that action. Other rules indicate the autonomy the nursing presents on the organization of its actions, such as the NCS defined in COFEN Ordinance n. 358/2009, which in article 3 states that "the nursing process must be based on a theoretical support that guides data gathering, nursing diagnosis development, and nursing actions or interventions planning, and which provides a basis for assessment of nursing results reached"(9).

That social movement of the profession aims at actualizing work, sharing ideas and knowledge, and providing assistance to the health needs of the population. Professional status expands and establishes itself, from the relation between the true knowledge that is constructed within professions and the way they use it, in order to convert efforts, alongside society, into well-being, health, quality and respect to human life.

Analyzing Freidson's ideas, "[he] believes it is the highest expression of a professional: transparency, public responsibility and attention to the well-being of our global village"(4) . The view the profession has of itself and of the environment it is part of outlines the search for expertise and resorts to self-regulation, thus influencing social structure and granting the occupation a certain professional status. That movement is made in a continuum that prescribes and rewrites the history of professions.

\section{Study limitations}

It comprises the authors' discussion and the Freidsonian framework, regarding his position on nursing being a para-profession.

\section{Contributions to nursing, public health or public policies field}

Defense argument of nursing as a profession, through the characteristics of autonomy, credentialism and expertise in a sociological approach. The article instigates professionals' movement in involvement with nursing causes, aiming at a collective fight for professional valuing and visibility.

\section{FINAL CONSIDERATIONS}

From the interpretation of sociological concepts of profession, based on Eliot Freidson and on nursing history, the conclusion is that the social dynamic of the profession aims at work actualization and at sharing knowledge, focusing on the needs of and assistance to the population's health. Therefore, the internal visibility that the profession holds of itself and of the environment it comprises legitimates the outlining of expertise, provides grounds for selfregulation and sets up its professional status. This movement of reflecting upon and knowing how the profession is conceptualized and is organized makes the acknowledgement and the necessity for the nursing profession evident, within society.

Certainly, with the perception of all the nursing development context within the last 30 years, considering the analysis based on Freidson, transformations arise from the production of knowledge, the expansion of care from individual to collective, and the expansion of employment both in public and private institutions. Tied to that, there are changes to shared care models and to credentialism consolidated in normalizations and public policies, which require professional competence in technical, scientific, technologic, ethical and systemized scope.

This interpretation of Sociology of Professions for nursing meets the goals of World Health Organization for the Nursing Now Program. It corroborates the strengthening of educational, labor, research and leadership of nursing professionals. Considering that, in order to reach autonomy and professional status, there are challenges regarding labor, distribution of professionals and to the understanding that professional protagonism is proportional to the portrait that the nursing community itself has of its own value. 


\section{REFERENCES}

1. Freidson E. Profissão médica: um estudo de sociologia do conhecimento aplicado. São Paulo: Editora UNESP; 2009.

2. Pereira Neto A. Eliot Freidson: progression and constraints in the biography of an intellectual. Hist Cienc Saude-Manguinhos. 2009;16(4):941-60. doi: 10.1590/S0104-59702009000400006

3. Pires DEP. Necessary changes for advancing Nursing as caring Science. Rev Bras Enferm. 2013;66(esp):39-44. doi: 10.1590/ S0034-71672013000700005

4. Freidson E. Profissionalism. The third logic. Chicago: The University of Chicago press; 2001.

5. Padilha MI, Bellaguarda MLR, Nelson S, Maia ARC, Costa R. He use of sources in historical research. Texto Contexto Enferm. 2017;26(4): e2760017. doi: 10.1590/0104-07072017002760017

6. Bellaguarda MLR, Padilha MI, Pires DEP. Regional nursing council of santa catarina (1975-1986): Importance for the profession. Texto Contexto Enferm. 2015;24(3):654-61. doi: 10.1590/0104-07072015003750013

7. Bardin L. Análise de conteúdo. São Paulo: Edições 70; 2016.

8. Pires DEP, Bellaguarda MLR, Zago AT, Matos E. Série Cadernos Enfermagem Consolidação da Legislação e Ética Profissional. Florianópolis: Coren-SC; 2010.

9. Conselho Federal de Enfermagem (COFEN). Resolução 358, de 15 de outubro de 2009. Dispõe sobre a Sistematização da Assistência de Enfermagem (SAE). [cited 2018 May 21]. Available from: http://www.site.portalcofen.gov.br/node/4384.

10. Bellaguarda MLR, Padilha MI, Peres MAA, Paim L. The nursing profession: its status - that is the question. Rev Enferm UERJ. $2016 ; 24(2):$ e8591. doi: 10.12957/reuerj.2016.8591

11. Bellaguarda MLR, Padilha MI, Pereira Neto AF, Pires D, Peres MAA. Reflection on the legitimacy of the autonomy at nursing in the field of the health professions in the light of Eliot Freidson's ideas. Esc Anna Nery. 2013;17(2):369-74. doi: 10.1590/S1414-81452013000200023

12. Pimenta AL, Souza ML de. The professional identity of nursing in the papers published by Reben. Texto Contexto Enferm. 2017;26(1): e4370015. doi: 10.1590/0104-07072016004370015

13. Pires DEP. Nursing as discipline, profession, and labour. Rev Bras Enferm. 2009;62(5):739-44. doi: 10.1590/S0034-71672009000500015

14. Schmitz EL, Gelbcke FL, Bruggmann MS, Luz SCL. Philosophy and conceptual framework: collectively structuring nursing care systematization. Rev Gaúcha Enferm. 2016;37(esp):e68435. doi: 10.1590/1983-1447.2016.esp.68435 